\title{
Oral treatment of hæmophilia A by gastrointestinal absorption of factor VIII entrapped in liposomes
}

Citation for published version (APA):

Hemker, H. C., Muller, A. D., Hermens, W. T., \& Zwaal, R. F. A. (1980). Oral treatment of hæmophilia A by gastrointestinal absorption of factor VIII entrapped in liposomes. Lancet, 315(8159), 70-71. https://doi.org/10.1016/S0140-6736(80)90495-X

Document status and date:

Published: 12/01/1980

DOI:

10.1016/S0140-6736(80)90495-X

Document Version:

Publisher's PDF, also known as Version of record

\section{Please check the document version of this publication:}

- A submitted manuscript is the version of the article upon submission and before peer-review. There can be important differences between the submitted version and the official published version of record.

People interested in the research are advised to contact the author for the final version of the publication, or visit the DOI to the publisher's website.

- The final author version and the galley proof are versions of the publication after peer review.

- The final published version features the final layout of the paper including the volume, issue and page numbers.

Link to publication

\footnotetext{
General rights rights.

- You may freely distribute the URL identifying the publication in the public portal. please follow below link for the End User Agreement:

www.umlib.nl/taverne-license

Take down policy

If you believe that this document breaches copyright please contact us at:

repository@maastrichtuniversity.nl

providing details and we will investigate your claim.
}

Copyright and moral rights for the publications made accessible in the public portal are retained by the authors and/or other copyright owners and it is a condition of accessing publications that users recognise and abide by the legal requirements associated with these

- Users may download and print one copy of any publication from the public portal for the purpose of private study or research.

- You may not further distribute the material or use it for any profit-making activity or commercial gain

If the publication is distributed under the terms of Article $25 \mathrm{fa}$ of the Dutch Copyright Act, indicated by the "Taverne" license above, 
Reverse transformation seemed to affect only tumour cells, since no effect was observed in the normal skin, mucosae, or other epithelial tissues. The selective character of this action explained the absence of toxicity of thioproline treatment.

The lack of activity of thioproline in experimental transplanted rodent tumours was not considered a setback. Serial transplantation might have caused important modifications of cell membranes which, while apparently not affecting tumour growth and response to cytotoxic drugs, might have impaired the response to the normal regulatory mechanisms of cell function that depend on membrane receptors.

This study was supported by a grant from the Spanish Ministry of Health and Social Security.

Requests for reprints should be addressed to A. B., Department of Oncology, Hospital General de Asturias, Oviedo, Spain.

\section{REFERENCES}

1. Gosalvez M, Vivero C, Alvarez I. Restoration of contact inhibition of tumor cells in tissue culture by treatment with thiazolidin-4-carboxylic acid. Biochem Soc Transact 1979; 7: 191-92.

2. Puck TT. Cyclic AMP, the microtubule microfilament system and cancer. ProcNatAcad SciUSA 1977; 74:4491-95.

3. Johnson GS, Friedman RH, Pastan I. Morphological transformation of cells in tissue culture by dibutyryl adenosine cyclic $3^{\prime} 5^{\prime}$ monophosphate. Proc Nat Acad Sci USA 1975; 68: 425-29.

4. Gosalvez M. The plasma membrane as the target in anticancer chemotherapy. Proc AACR and ASCO 1979;20:17.

\section{ORAL TREATMENT OF HEMOPHILIA A BY GASTROINTESTINAL ABSORPTION OF FACTOR VII ENTRAPPED IN LIPOSOMES}
H. C. HEMKER
W. Th. HERMENS
A. D. Muller
R. F. A. ZWAAL

Department of Biochemistry, Biomedical Centre, State University of Limburg, Maastricht, Netherlands

Summary Factor-VIII-loaded liposomes were given orally to a patient with severe hæmophilia A. Plasma concentrations of factor VIII rose to therapeutically effective levels, that persisted for 50 hours.

\section{INTRODUCTION}

HæMOPHiLia $A$ is caused by a sex-linked congenital lack of functional coagulation factor VIII. Coagulation factor VIII is a plasma protein, as yet not well characterised but associated with a protein complex with a molecular weight of 2000000 . In current treatment and prophylaxis of hæmophilia A, partly purified preparations of this protein are administered intravenously. We describe a preparation consisting of liposomes loaded with factor VIII that, when administered orally to a hæmophilic patient, produced a rise in plasma factor VIII procoagulant activity.

Liposomes are artificial structures that consist of multiple concentric bilayers of phospholipids. ${ }^{1}$ Proteins may be entrapped in the interstices between the bilayers. ${ }^{2}$ When liposomes are prepared in the presence of an aqueous solution of an enzyme, $5-15 \%$ of the enzyme or enzyme-protein may become enclosed in these structures. $^{2-4}$ Liposome-entrapped proteins entered intact cells and insulin-loaded liposomes administered orally caused a drop in blood glucose in diabetic rats. ${ }^{5}$ Because factor VIII has been reported to interact hydrophobically with phospholipids when involved in blood coagulation, ${ }^{6}$ we thought that it might be possible preferentially to absorb factor VIII on phospholipids and in this way obtain liposomes with a high factor-VIII content in which factor VIII was relatively stable.

Despite problems associated with oral administration of matter contained in liposomes, ${ }^{7}$ we thought that because of the specific binding of factor VIII to lipids, administration of factor-VIII-loaded liposomes to a hæmophilic patient might raise the plasma factor VIII content.

\section{METHODS}

We prepared factor-VIII-loaded liposomes by shaking a factor VIII solution with glass beads in a flask, the wall of which had been coated with phospholipids. A $200 \mathrm{ml}$ round-bottomed flask was coated with $250 \mathrm{mg}$ of egg lecithin containing 5\% $(w / w)$ of phosphatidic acid, by addition of lecithin in ethanol and evaporation of the solution to dryness in a rotary evaporator under reduced pressure. Then $5 \mathrm{ml}$ of the factor VIII solution and a few glass beads were added and the flask was shaken gently until all lipid was removed from the flask wall.

The suspension obtained was centrifuged for $30 \mathrm{~min}$ at $27000 \mathrm{~g}$ at $10^{\circ} \mathrm{C}$ which caused the liposomes to float. The aqueous phase was taken out with a hypodermic syringe and used to make a second liposome preparation as described above. Both liposome preparations were pooled and washed once with isotonic saline followed by centrifugation at 50000 $g$ for $10 \mathrm{~min}$. The liposomes were pelleted and diluted to a volume of $50 \mathrm{ml}$ with isotonic saline before oral administration. A more detailed description of the method has appeared elsewhere. ${ }^{8}$

We used factor VIII prepared by cryoprecipitation (AHF Konzentrat SRK [human], Zentral Lab. Blutspendedienst SRK, Switzerland). The freeze-dried material in each ampoule was dissolved in $8 \mathrm{ml}$ of twice-distilled water, and this yielded a preparation containing $7.5 \mathrm{mg} / \mathrm{ml}$ of fibrinogen and $43-45$ units of factor VIII per $\mathrm{ml}$ (one unit of factor VIII is defined as the amount contained in $1 \mathrm{ml}$ of fresh normal plasma).

The supernatant of the saline wash was combined with the infranatant fluid obtained after the second entrapment and factor VIII and fibrinogen were determined. It seemed that this fluid contained $19-22 \%$ of the original factor VIII and $76-79 \%$ of the fibrinogen. This shows that the liposome preparation is indeed preferentially enriched with factor VIII, probably because of interaction between factor VIII and the lipid bilayer shells.

\section{RESULTS}

Plasma factor-VIII activity rose on all three occasions when a liposome preparation of factor VIII was given before breakfast to a patient with severe hæmophilia (mean factor VIII level when not on treatment less than $0.5 \%$ of normal; no circulating antibodies). The results in one of the three experiments are shown in the accompanying figure. Plasma concentrations after the same amount of factor VIII had been administered intravenously are also shown. The patient had hæmaturia before ingestion of the liposome preparation; this disappeared on the day of the experiment and returned on the third day after the experiment. Plasma factor-VIII activity did not rise when either liposomes or factor VIII were administered separately.

Some of the factor VIII administered in the liposomes appeared in the plasma as factor-VIII activity. It took 


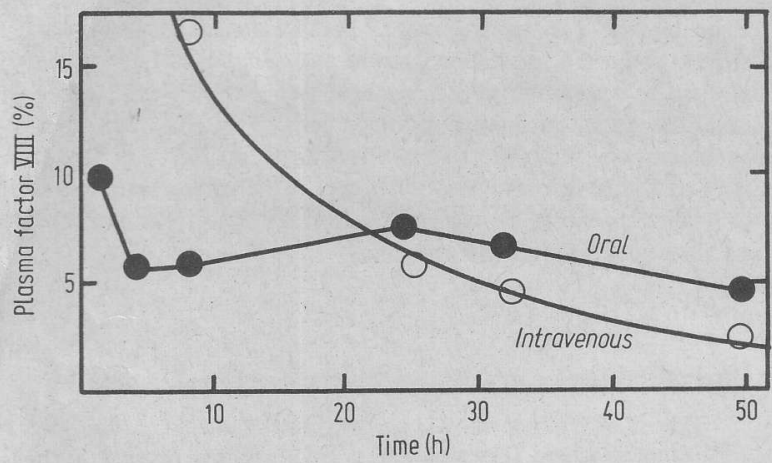

Factor-VIII activity in plasma after oral and intravenous administration of factor VIII to a patient with severe hæmophilia.

Concentrations were determined according to Veltkamp ${ }^{10}$ and are expressed as percentage of factor VIII concentration in pooled normal plasma $(n=30)$. Each sample was tested four times. SEM did not exceed $9 \%$ of value observed. At zero time 800 units of factor VIII were given orally or intravenously. Factor VIII concentration in the untreated subject is less than $0.5 \%$ of normal. Concentrations after intravenous administration measured before $9 \mathrm{~h}$ were between $30 \%$ and $15 \%$ and have been omitted from graph.

longer for high levels of plasma-factor-VIII activity to be reached after oral administration than after intravenous administration. It seems that orally administered factor VIII does not enter the plasma directly but enters via an as yet unknown depot. We could not test whether such a depot could be loaded more efficiently by intravenous injection of the liposomes since our laboratory does not routinely treat patients with hæmophilia A. For the same reason we can report here on experiments in one patient only.

\section{DISCUSSION}

Oral administration of factor VIII may give better results than intravenous injection. The apparently reduced effect on clotting activity immediately after ingestion is compensated by the maintenance of therapeutic concentrations on the second day after administration. Since concentrations of between 5 and $10 \%$ of normal are usually sufficient for prophylaxis and treatment of minor bleeds ${ }^{9}$ and concentrations of $25-35 \%$ are sufficient for major bleeds and surgical cover, ${ }^{9}$ in practice the efficacy of a dose of factor VIII given orally may be as high as that of the same dose given intravenously.

\section{REFERENCES}

1. Bangham AD, Standish MM, Weissmann G. The action of steroids an streptolysin $\mathrm{S}$ on the permeability of phospholipid structures to cations. $\mathscr{F}$ Mol Biol 1965; 13: 253-59.

2. Sessa G, Weissmann G. Incorporation of lysozyme into liposomes. A mode for structure-linked latency. F Biol Chem 1970; 245: 3295-301.

3. Weissmann G, Bloomgarden D, Kaplan, et al. A general method for the introduction of enzymes, by means of immunoglobulin-coated liposomes into lysosomes of deficient cells. Proc Natl Acad Sci 1975; 72: 88-92.

4. Cohen CM, Weissman G, Hoffstein S, Awashti Y, Srivastava SK. Introduction of purified hexosaminidase A into Tay-Sachs leukocytes by means of immunoglobulin-coated liposomes. Biochemsistry 1976; 15: 452-60.

5. Patel HM, Ryman BE. Oral administration of insulin by encapsulation within liposomes. FEBS Letters 1976; 62: 60-63.

6. Hemker HC, Kahn MJP. The reaction sequence of blood coagulation. Nature 1967; 215: 1201-02.

7. Gregoriadis G, Siliprandi N, Turchetto E. Possible implications in the use of exogenous phospholipids. Life Sci 1977; 20: 1773-86.

8. Hemker HC. Dutch patent application O.A. 79.00459 (1979).

9. Biggs R, Macfarlane RG. Hæmophilia and related conditions: a survey of 187 cases. Brf Hoemat $1958 ; 4: 1-17$.

10. Veltkamp JJ, Drion EF, Loeliger EA. Detection of the carrier state in hereditary coagulation disorders. Thromb Diath Hamorrh 1968; 19: 279-287.

\section{Reviews of Books}

\section{Birth Control}

An International Assessment. Malcolm Potts and Pouru BhiwANDIWALA, International Fertility Research Program. Lancaster: M.T.P. Press. 1979. Pp. 305. $£ 12.95$

EIGHTEEN authors from four continents have produced this well-written, interesting, and timely review of global familyplanning programmes. Not surprisingly, there is some unevenness in the quality of the writing, but all the authors are experts in their field. The brevity of much of the writing is a tribute to skilful editing. The three parts of the book consist of a section on mother and child, an encouraging report of successful family-planning programmes, and a somewhat less cheerful look at barriers and bottlenecks. There are two particularly good chapters in this last section. In an essay remarkable for both common sense and economy of writing Dr Roger Short of Edinburgh looks at future developments in fertility control. Dr Short believes that fundamentally new contraceptives are so bedevilled by technical difficulties that none is likely to be introduced before the end of this century. He considers that if we are to be realistic we must admit that the main changes in contraceptives in the next twenty years are likely to be a combined oral contraceptive pill with a lower incidence of side-effects and probably a more reliable intrauterine device, also with fewer side-effects. A systemic new male contraceptive can have disadvantages. Dr Short tells us that "compounds that inhibit the spermatogenic activity of the testis also inhibit its androgen production, and rightly or wrongly men think that their androgen levels are necessary for their libido, aggression, drive, machismo and all those other characteristics that make us so objectionable - and so fascinating!" Dr Hugo Corvalán, the United Nations Family Planning Association regional coordinator in Colombia, reviews "the abortion epidemic". What happens in his own Latin America makes chilling reading. In some places over $40 \%$ of all consultations in hospital were related to the complications of abortions and more than $25 \%$ of the scarce blood available for transfusion was used for hæmorrhages following illegal abortions. In Chile, where abortion is illegal, there is one death for every 250 women who come to hospital for the complications of induced abortion, whereas in Yugoslavia and other countries where abortion is legal, the chance of death is 1 in 16000 . Dr Corvalán, drawing heavily on the work of the Chilean demographer Requena, shows most effectively how, as socioeconomic conditions and expectations improve, so does the desire to control one's fertility. Initially the use of contraception increases dramatically. At the same time the numbers of induced abortions also rise sharply, largely because of contraceptive failures. Abortion rates then fall equally dramatically once contraceptive usage becomes widely accepted and effectively provided. This excellent book should be useful to all those interested in international and national family-planning programmes. However, its price may prevent it reaching as wide a readership as it deserves.

\section{The Epstein-Barr Virus}

Edited by M. A. EPsTeIn and B. G. Achong, University of Bristol. Berlin and New York: Springer-Verlag. 1979. Pp. 459. \$66; DM120.

THE usual image of a herpesvirus infection is a vesicular eruption on the skin which may be of one of two types (zoster or simplex), and which may or may not respond to an antiherpes drug. The electron microscope has changed all that, and now the extended view of herpesviruses (i.e. viruses which are morphologically the same as herpes simplex and zoster) 
takes in two other major pathogens of man. These are cytomegalovirus (CMV) and Epstein-Barr virus. Epstein-Barr virus is now identified as the cause of infectious mononucleosis, Burkitt's lymphoma, and nasopharyngeal carcinoma. CMV is well characterised and, on its epidemiological track record, is at least as important a human pathogen as either simplex or zoster, with 400 mentally abnormal children born each year, in England and Wales alone, to be laid at its door. Epstein-Barr virus is less easy to grow and perhaps less easy to understand, but has been at least as much studied as CMV. Epstein and Achong, in their opening chapter of this book, claim that EBV is "the first viral agent to be discovered solely by electron microscopy". The book, it is claimed, is ". . . the first and only comprehensive, authoritative over-view of all aspects of the virus, by authors who have been the original and major contributors in their particular disciplines". Although the virus grows very poorly in vitro, and is, by conventional standards, not "a virologist's virus", it has, nevertheless, a double interest, on the one hand as the causal organism of glandular fever, and on the other as the first virus known to cause human cancer, and it is this which has led to the intense work on it in the fifteen years since it was discovered. The editors have drawn upon a very distinguished group of virologists, who have written on all aspects of the agent. These include molecular probes for viral DNA, the comparative virology of animal oncogenic herpesviruses, and the epidemiology of Burkitt's lymphoma. There is even, to end on a hopeful note, a chapter on the possibility of vaccination against the virus, and hence against the cancer it causes. The multiplicity of authorship does not easily show through. This well-integrated and elegantly produced book is unlikely to be superseded for a long time. It is strongly recommended to all those dealing in human virology. It should be cherished by virologists, studied by oncologists, and certainly not ignored by cell biologists.

\section{Advances in Human Genetics}

Vol. IX. Edited by H. HARRIS, University of Pennsylvania, and K. Hirschrorn, Mount Sinai School of Medicine, City University of New York. New York and London: Plenum Press. 1979. Pp. 379. \$35.

THIs series is now well established as providing authoritative reviews of growing points in human genetics, and the current volume is no exception. D. G. Harnden and A. M. R. Taylor's chapter on chromosomes and neoplasia includes not only well-documented descriptions of cytogenetic abnormalities associated with various neoplasms, but also speculation on the possible relevance and significance of these findings in regard to pathogenesis. This chapter is a model of clarity and precision. The critical examination, by J. M. Opitz and colleagues, of the vexed problems of terminology and nosology of birth defects is a tour de force in this notoriously confusing field. To some, arguments over definitions may seem pedantic, but precision is essential if the ætiology of these malformations is ever to be understood. The discovery in recent years of the diagnostic value of alpha-fetoprotein levels in serum for hepatocarcinoma, and in amniotic fluid for neural-tube defects, has prompted considerable research in this protein. More recently increasing interest has focused on the possible role of AFP as an immunoregulatory factor and on the immunological relationship between mother and fetus. M. Adinolfi presents a balanced and very readable review of the diagnostic uses and biological functions of this intriguing protein. The genetic control of hæmoglobin synthesis, reviewed by W. P. Winter, S. M. Hanash, and D. L. Rucknagel, has both theoretical and practical importance, especially now that, with DNA hybridisation, prenatal diagnosis of certain hæmoglobinopathies is possible from the study of amniotic-fluid cells. Unfortunately this most exciting development is only touched upon. Also of special interest to the hæmatologist is the concluding chapter by R. W.
Erbe on the genetic aspects of folate metabolism which involves some 16 or more enzymes, many of which can be studied in accessible tissues such as lymphocytes and cultured skin fibroblasts and amniotic-fluid cells. This is a book for the specialist, some might say the ultra-specialist, for it is doubtful if even many human geneticists would be conversant with all the subjects dealt with. As a source book on the particular subjects covered, it is invaluable.

\section{Current Practice of Clinical Electroencephalography}

Edited by Donald W. KLoss, Mayo Medical School, Rochester, Minnesota, and DAVID D. DALY, Southwestern Medical School, Dallas, Texas. New York: Raven Press. 1979. Pp. 532. \$58.50.

THE preface to this well set-out text, accompanied by excellent illustrations, explains that there are several omissions because the volume is not meant to be encyclopædic. Instead it is a book containing the views of North American experts. Both editors belong to this category, as do all the other contributors. A quick search through the index does reveal some surprising omissions. Frontal intermittent rhythmic delta activity (FIRDA) and projected rhythms are not included. However, "flat" tracings are quite rightly included because, although this term is frowned on by electroencephalographers, it is widely used by physicians. The first two chapters emphasise medicolegal matters. There follow practical and useful chapters on basic visual analysis, artefact, and an orderly approach to EEG reporting. Then comes a lucid and authoritative account of the EEG of premature and full-term newborn babies. Current views are summarised in the sections on the EEG in epilepsy, focal lesions, and diffuse brain disorders. Surprisingly, the section on evoked responses is a mere 10 pages, despite the vast expansion in this area in the U.S. An unusual feature is an appendix where the contributors discuss groups of chapters; these discussions reveal both areas of controversy and areas of general agreement. Clearly, the editors had in mind a handbook for the postgraduate taking the American Boards in electroencephalography. However, the book is valuable for a much wider readership.

\section{Electron Microscopy of the Kidney in Renal Disease and Hypertension}

A Clinicopathological Approach. A. K. MANDAL in collaboration with J. E. WENZL, University of Oklahoma College of Medicine. New York and London: Plenum. 1979. Pp. 452. \$32.

THIs readable textbook is characterised by an abundance of electronmicrographs. The first chapter, on microscopy for the physician, is both factual and helpful and, as the author notes, is derived from Leeson and Leeson's Histology. The chapter on the clinical assessment of the ætiology and pathological activity of glomerulonephritis seems irrelevant, since it is intended to be a guide to the biochemical investigation of glomerulonephritis. That on the pathogenesis and classification of glomerulonephritis is clear and well written. Others are rather superficial - for example, the one on the "Pathology.of the Kidney in Profiling Acute Renal Failure (Acute Uremia)" (sic), which covers diverse subjects. The electronmicrographs and occasional other illustrations vary considerably in quality, their defects reflecting perhaps as much shortcomings of reproduction as deficiencies in the original plates. Membranous glomerulonephritis, a condition which is superbly illustrated in most general textbooks, is very poorly illustrated here. In short, this book differs from the classical texts of Hamburger, Heptinstall, or Zollinger, in that it is neither balanced nor comprehensive. It has the merit of being more lavishly illustrated by electronmicrographs than any of these texts, although many of the electronmicrographs scarcely merit inclusion. 